\title{
Food consumption by yellowtail flounder in relation to production of its benthic prey
}

\author{
Jeremy S. Collie* \\ Woods Hole Oceanographic Institution, Woods Hole, Massachusetts 02543, USA
}

\begin{abstract}
Yellowtail flounder Limanda ferruginea consumes a small but significant proportion of the production of its invertebrate prey. Using 2 different methods, I calculated rate of food consumption by yellowtail flounder at 3 sites off the New England coast, USA. The bioenergetic method sums the food required to satisfy the metabolic needs of the fish. The second method is based on weight of stomach contents and rate of food evacuation from the stomach. The bioenergetic method gave consistently higher results $\left(1.4\right.$ to $\left.1.6 \mathrm{~kg} \mathrm{fish}^{-1} \mathrm{yr}^{-1}\right)$ than the stomach-content method $(0.5$ to $0.8 \mathrm{~kg}$ fish $^{-1} \mathrm{yr}^{-1}$ ). Yellowtail flounder abundance was estimated with a method that uses commercial-catch data to standardize a survey: relative-abundance index. I multiplied consumption rates per fish by flounder density to obtain estimates of consumption per unit area, which range from 1.2 to $6.3 \mathrm{~g}$ wet wt $\mathrm{m}^{-2} \mathrm{yr}^{-1}$. Annual production of 6 important prey species was calculated from benthic samples collected concurrently at the same sites. Yellowtail flounder consumption as a percentage of prey production was 6 to $12 \%, 2$ to $5 \%$, and 1 to $3 \%$, for the amphipods Unciola inermis, Ericthonius fasciatus and Ampelisca agassizi, respectively; 11 to $34 \%$ and 7 to $21 \%$ for the polychaetes Chone infundibuliformis and Nephtys incisa, respectively; and less than $1 \%$ for the sand dollar Echinarachnius parma.
\end{abstract}

\section{INTRODUCTION}

Benthic macrofauna are an important link between primary production and fish production in the Georges Bank food web (Sissenwine et al. 1984). Ultimately, fish production is limited by food supply but, at present, one can only roughly approximate the extent to which demersal fish utilize available prey. The purpose of this paper is to examine the consequences of predation by the yellowtail flounder Limanda ferruginea on its principal benthic prey species. The basic approach was to estimate the proportion of prey production consumed by yellowtail flounder and to infer from this proportion to what extent the flounder is food-limited and/or whether it regulates the abundance of its benthic prey.

Few studies of this type have been conducted because of the requirement of collecting data on both food habits and benthic production. Two studies in shallow bays on the Swedish west coast (Evans 1984,

\footnotetext{
- Present address: Institute of Animal Resource Ecology, University of British Columbia, 2204 Main Mall, Vancouver, British Columbia V6T 1W5, Canada
}

Pihl 1985) indicate that epifaunal predators are major biotic regulators of the benthic community. The predators were: juvenile plaice Pleuronectes platessa, 2 sand goby species, Pomatoschistus microps and P. minutus, brown shrimp Crangon crangon, and crab Carcinus maenas. Consumption by this guild of predators accounted for most of the annual production of the following prey: Corophium volutator (67 to $98 \%$ ), Mya arenaria (62\%), Cardium edule $(92 \%)$, C. crangon $(60$ to $80 \%$ ) and polychaete species ( $4 \%$ ).

Another method of inferring the consequences of predation is to correlate changes in the abundance of predator and prey populations over time. Arntz (1980) analyzed 8 yr of data on the abundance of macrofauna and demersal fish in the western Baltic Sea. Although fish preyed heavily on benthos, the abundance of one did not appear to depend on the abundance of the other. Persson (1981) inferred, from caging experiments, benthic surveys, and increased growth rate of flatfish, that increased macrobenthic populations in the Baltic Sea resulted from exploitation on the flatfish stocks.

The yellowtail flounder Limanda ferruginea (Storer) is a right-handed, small-mouthed flounder that 
inhabits the eastern seaboard of North America from Labrador to Chesapeake Bay, between 10 and $100 \mathrm{~m}$ depth (Bigelow \& Schroeder 1953). I chose the yellowtail flounder for this study because it feeds almost entirely on benthic macrofauna (Langton 1983, Bowman \& Michaels 1984) and is a commercially important species (Clark et al. 1984), which allows its abundance to be estimated from catch data.

Grosslein et al. (1980) used bioenergetic calculations to estimate the annual consumption by 6 fishes on Georges Bank. Yellowtail flounder consumed $2.9 \mathrm{~g}$ wet wt $\mathrm{m}^{-2} \mathrm{yr}^{-1}$ from 1964 to 1966 and $2.2 \mathrm{~g}$ wet wt m $\mathrm{m}^{-2}$ $\mathrm{yr}^{-1}$ from 1973 to 1975 . In this study I estimated consumption by using the consumption-to-biomass ratio (C/B) of Grosslein et al., and also by using a method based on stomach contents. Prey production rates were calculated from samples collected during the Georges Bank Benthic Infauna Monitoring Program (GBMP).

\section{METHODS}

Fish stomachs were collected on a quarterly basis from summer 1982 to spring 1983 on cruises conducted by the Northeast Fisheries Center (NEFC), Woods Hole, Massachusetts, USA. Stomach collection coincided as closely as possible with the dates and locations of benthic sampling conducted as part of the Georges Bank Benthic Infauna Monitoring Program (Battelle \& WHOI 1985). I chose monitoring Stns 5, 10 and 13 for fish-stomach analysis because the yellowtail flounder is relatively abundant at these sites. Stns 5 and 10 are located on the southern flank of Georges Bank at 84 and $60 \mathrm{~m}$ depth, respectively. Stn 13 at $69 \mathrm{~m}$ depth is located south of Nantucket in the fishing area known as 'Southern New England'. At each site trawling was conducted within a $5 \mathrm{~km}$ square centered at the station coordinates (see Collie 1985a, b for exact station locations).

At each station, a No. 35 bottom trawl was towed every $3 \mathrm{~h}$, over a $24 \mathrm{~h}$ period, in order to investigate diel feeding behavior. Tow duration was generally $30 \mathrm{~min}$ at 3.0 to 3.5 knots. At each station and date, the seawater temperature profile was measured by expendable bathythermograph and calibrated by a surface thermometer reading. Fish stomachs were excised at sea, preserved in $10 \%$ formalin in seawater and individually labelled. At the Battelle Laboratory (Duxbury, Massachusetts, USA) each stomach was cut longitudinally and the entire bolus removed and wet-weighted to the nearest $1 \mathrm{mg}$ after blotting. Stomach contents were sorted to species, which were counted and individuals of each species weighed together.

Consumption rate per fish was estimated by 2 methods: one based on bioenergetics and the other on stomach contents. According to the bioenergetic approach, consumption is the amount of food a fish requires to satisfy its total metabolic needs. Consumption $(C)$, in units of weight, can be calculated as:

$$
\mathrm{C}=(\mathrm{G}+\mathrm{S}+\mathrm{Q}) / \alpha
$$

where growth $(G)$, reproduction (S) and respiration (Q) are all functions of weight. Assuming an assimilation coefficient $(\alpha)$ of 0.8 , Grosslein et al. (1980) obtained a mean consumption-to-biomass ratio (C/B) of $4.6 \mathrm{yr}^{-1}$ for all ages during the years 1963 to 1972 . To determine consumption per fish, I multiplied $\mathrm{C} / \mathrm{B}$ by the mean weight of yellowtail flounder caught at Stns 5, 10 and 13 (Collie 1985b, Appendix B).

The stomach-content method of estimating consumption is based on the amount of food in the stomach and its rate of elimination. Durbin et al. (1983), in reviewing evacuation-rate studies, concluded that an exponential model of gastric evacuation provides a good fit to most experimental data. If one assumes that the ingestion rate is constant over a short sampling interval and that the hourly gastric evacuation rate (r) is proportional to the weight of food in the stomach (S), consumption during each time interval $(t)$ is:

$$
\mathrm{C}=\mathrm{rt}\left[\mathrm{S}_{\mathrm{t}}-\mathrm{S}_{0} \exp (-\mathrm{rt})\right] /[1-\exp (-\mathrm{rt})]
$$

(Elliot \& Persson 1978). I calculated the mean stomachcontent weight $\left(\mathrm{S}_{t}\right)$ from all stomachs (including empty ones) collected in each tow, and used Eqn (2) to calculate consumption during each interval over a $24 \mathrm{~h}$ period.

Fish with daily feeding patterns should have the same stomach-content weight at a given time on successive days. In this case daily ration $\left(\mathrm{C}_{24}\right)$ can also be calculated as:

$$
\mathrm{C}_{24}=24 \mathrm{r} \overline{\mathrm{S}}
$$

where $\overline{\mathrm{S}}=$ mean stomach-content weight over $1 \mathrm{~d}$ (Eggers 1979). Eqn (3) is applicable to samples with insufficient stomachs to apply Eqn (2). For each station and date, I calculated the mean stomach-content weight $(\bar{S})$ from all stomachs, and used the variance of $\overline{\mathrm{S}}$ to estimate the variance of consumption. Annual consumption was calculated by interpolating between quarterly sampling intervals.

The gastric evacuation rate, $r$, has been determined for several marine fishes but not for yellowtail flounder. Temperature, food type, food size, meal size and feeding regime all affect gastric evacuation rates (Fange \& Grove 1979); of these factors, temperature and food type are the most important. Durbin et al. (1983) found that the slopes of the relation between log (r) and temperature (T) were similar for different fishes, but the intercept depended on prey type. For several 
marine fishes (cod, flounder, menhaden) fed small prey (less than $0.5 \mathrm{~g}$ ), the relation between $\mathrm{r}\left(\mathrm{h}^{-1}\right)$ and $\mathrm{T}\left({ }^{\circ} \mathrm{C}\right)$ was:

$$
r=0.041 \exp (0.111 \mathrm{~T})
$$

I used this equation and the corresponding bottom temperatures to estimate gastric evacuation rates of yellowtail flounder.

To estimate yellowtail flounder density, I applied the Collie \& Sissenwine (1983) method to a 21 yr time series (1963 to 1983) of commercial-catch and research-survey data (Clark et al. 1984). This method uses the commerical-catch data to smooth the relativeabundance index and estimate a catchability coefficient relating the mean catch-per-tow to total population size. Stns 5 and 10 are on Georges Bank and Stn 13 is in the area inhabited by the Southern New England population. As these populations are more or less discrete and their catch statistics are compiled separately, I estimated the size of both populations. Yellowtail flounder consumption per unit area is the consumption rate per fish multiplied by population size and divided by the area of the survey strata in which the population lives (Frank P. Almeida, NEFC, pers. comm.).

Annual production rates of 6 important prey species were determined from benthic samples collected as part of the GBMP (Battelle \& WHOI 1985). Production of 3 amphipod species (Unciola inermis, Enicthonius fasciatus and Ampelisca agassizl) and 1 sand dollar species (Echinarachnius parma) was estimated (Collie $1985 \mathrm{a}$, b) by the growth-increment method (Crisp 1984). In this study I also calculated the production of 2 polychaete species, Chone infundibuliformis and Nephtys incisa. Size-frequency distributions of $C$. infundibuliformis were determined in 5 quarterly samples taken at Stn 13 from July 1982 to July 1983 (Battelle \& WHOI 1985, Fig. 88). I used the size-frequency (Hynes) method of estimating production, as modified by Krueger \& Martin (1980), because cohorts are not apparent in these distributions.

In the size-frequency method the size distribution of an 'average' cohort is obtained by averaging the frequencies in each size class over the year. Production (P) is then calculated as the sum of biomass removed between successive size classes, according to:

$$
P=a\left[\sum_{j=1}^{a}\left(N_{j}-N_{j+1}\right)\left(w_{j} w_{j}+1\right)^{0.5}\right]
$$

where $N_{j}=$ mean number in size class $\mathrm{j}$ averaged over the sampling dates; $w_{j}=$ mean weight per individual of size class j; and $\mathrm{a}=$ number of size classes. Krueger \& Martin (1980) recommended that the geometric mean weight, $\left(w_{j} w_{j+1}\right)^{0.5}$, be used, because it is more accurate for logarithmic growth patterns. The sizefrequency method, though it does not rely on being able to identify cohorts in the size-frequency distributions, does assume that the average life-span is known. It also assumes that the growth rate is linear, that all individuals could grow to the maximum size and that the year-to-year population size is the same.

According to Wildish \& Peer (1983), Chone infundibuliformis is an annual species; this is consistent with the length-frequency data in Battelle \& WHOI (1985), which suggested that recruitment occurs in spring and early summer. I used a length-weight regression for $C$. infundibuliformis (Collie 1985b, Table 2-2) to convert length to weight. Having estimated production of $C$. infundibuliformis at Stn 13, I used the production-to-biomass ratio $(\mathrm{P} / \mathrm{B})$ to estimate production of this species at Stn 5, from which samples of C. infundibuliformis were not measured.

Production of Nephtys incisa at Stn 13 was calculated using P/B estimated from 2 other locations on the East Coast. For Long Island Sound, Sanders (1956) calculated a production rate of $9.35 \mathrm{~g}$ wet wt $\mathrm{m}^{-2} \mathrm{yr}^{-1}$ and $\mathrm{a} \mathrm{P} / \mathrm{B}$ of 2.16 . Off the Delaware coast, $N$. incisa

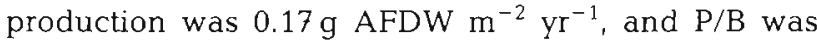
found to be 2.23 (Howe \& Leathem 1984). I applied these $\mathrm{P} / \mathrm{B}$ values to the $N$. incisa mean biomass data from Stn 13.

To calculate yellowtail flounder consumption as a function of prey production it was necessary to partition total consumption by percent diet composition. I calculated a weighted mean percent of each prey species in the diet and applied these percentages to the overall food consumption rate. Finally I divided the consumption rate for each prey species by the corresponding prey production rate.

\section{RESULTS}

A total of 594 yellowtail flounder stomachs were examined; 400 of these contained recognizable food; 194 were empty. Most of the yellowtail flounder were between 26 and $35 \mathrm{~cm}$ long, corresponding to an age of 3 yг (Lux \& Livingston 1982). The stomach contents of these fish are tabulated, by numbers and by weight, in Collie (1985b, Appendix B). At each station and date, a few prey species constituted the bulk of the yellowtail flounder diet. Amphipods dominated the diet numerically; polychaetes were important on a weight basis (Fig. 1). The mean weights of yellowtail flounder, averaged over the year, caught at Stns 5, 10 and 13 were 348.1, 298.1 and 333.0 g (Collie 1985b) which, when multiplied by $4.6 \mathrm{yr}^{-1}$, give consumption rates of 1.60 , 1.37 and $1.53 \mathrm{~kg}$ wet wt fish ${ }^{-1} \mathrm{yr}^{-1}$, respectively.

The second method of estimating consumption uses the weights of the stomach boli and sea-bottom temperatures, listed in Table 1. Typically, the distribution 


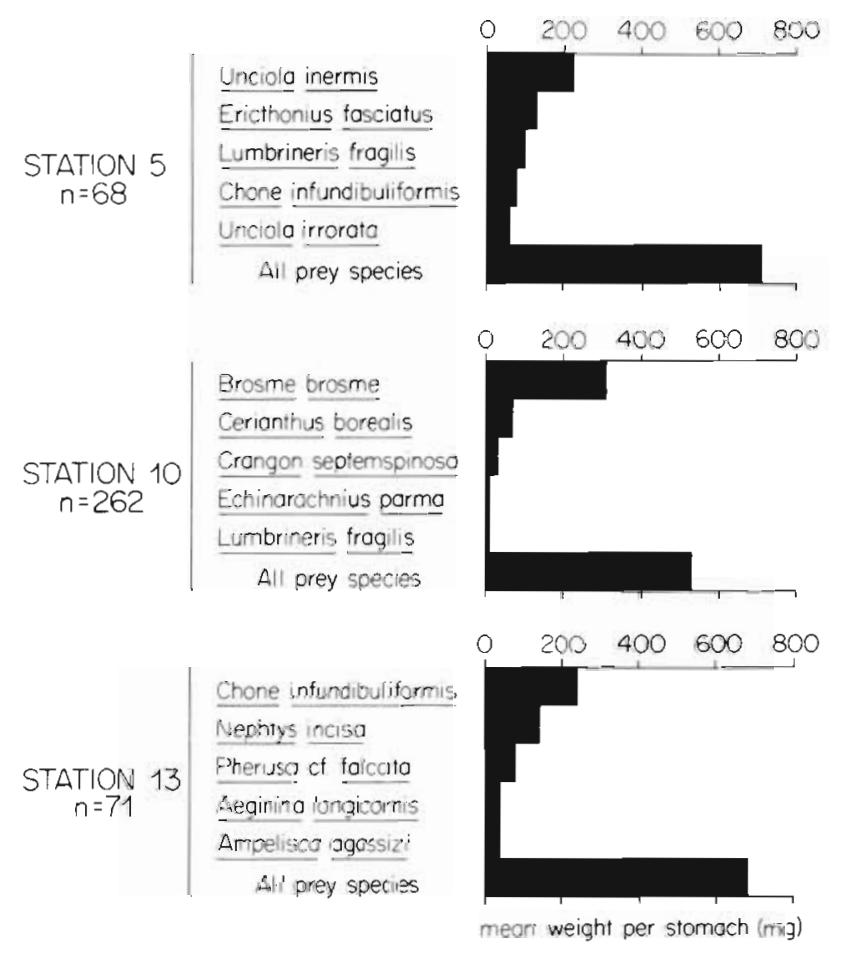

Fig. 1. Limanda ferruginea. The 5 most important prey species of yellowtail flounder in units of wet weight. Data are weighted means of 4 (quarterly) collecting cruises

of stomach-content weights is quite skewed with a few of the stomachs containing most of the food. The percentage of empty stomachs, which ranged from 8.3 to $65.4 \%$, explains some of the variation in mean stomach-content weight among dates and stations. In other words, the high standard deviations of stomachcontent weight are caused not only by how much the fish eat, but also when they feed.

In only 2 cases (Aug 1982 and May 1983 at Stn 10) were enough stomachs collected to apply the change-

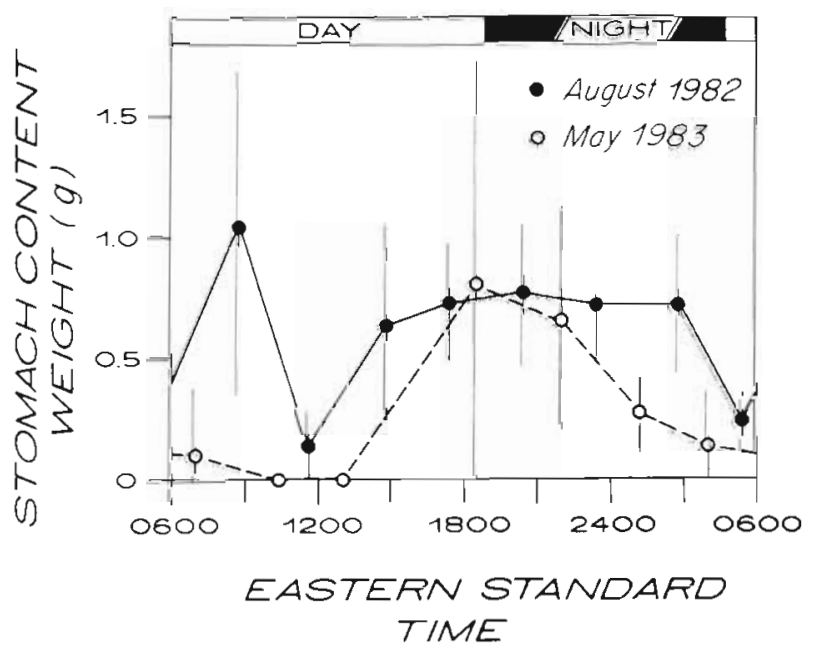

Fig. 2. Limanda ferruginea. Change in yellowtail flounder stomach-content weight over $24 \mathrm{~h}$. Vertical lines are $95 \%$ confidence intervals

in-stomach-content method (Eqn 2). A diel trend in stomach-content weight is apparent on both sampling dates (Fig. 2). The large confidence intervals are due, in some cases (e.g. $0840 \mathrm{~h} / \mathrm{Aug}$ and $1830 \mathrm{~h} / \mathrm{May}$ ), to small sample sizes ( $\mathrm{n}=8$ and 7 , respectively). In general, the variance of stomach-content weight is high because not all fish feed at the same time and there are many empty stomachs at any time of day.

If one ignores the small sample value for $0840 \mathrm{~h} /$ August, stomach-content weight is lowest in the morning ( 0600 to $1200 \mathrm{~h})$ and highest in the evening (1800 to $2400 \mathrm{~h}$ ). The evacuation rate, as calculated from Eqn (4) and the temperatures in Table 1 , was $0.142 \mathrm{~h}^{-1}$ in August 1982 and $0.097 \mathrm{~h}^{-1}$ in May 1983. The ingestion rate, calculated by Eqn (2), was highest from 1200 to $1800 \mathrm{~h}$, then continued at a low level until $2400 \mathrm{~h}$. The sum of consumption over $24 \mathrm{~h}$ was $2.06 \mathrm{~g}_{\text {wet }} \mathrm{wt} \mathrm{d}^{-1}$ in August 1982 and $0.76 \mathrm{~g}$ wet wt $\mathrm{d}^{-1}$ in May 1983.

Table 1. Limanda ferruginea. Yellowtail flounder stomach-content wet weights

\begin{tabular}{|c|c|c|c|c|c|c|}
\hline \multirow[t]{2}{*}{ Date } & \multirow[t]{2}{*}{ Station } & \multicolumn{2}{|c|}{ Content weight $(g)$} & \multicolumn{2}{|c|}{ No. of stomachs } & \multirow{2}{*}{$\begin{array}{l}\text { Bottom } \\
\text { temp. }\left({ }^{\circ} \mathrm{C}\right)\end{array}$} \\
\hline & & Mean & SD & Total & Non-empty & \\
\hline \multirow[t]{3}{*}{ Aug 1982} & 5 & 1.179 & 1.188 & 12 & 11 & 9.5 \\
\hline & 10 & 0.592 & 0.711 & 244 & 176 & 11.3 \\
\hline & 13 & 0.165 & 0.422 & 10 & 4 & 12.1 \\
\hline Oct 1982 & 5 & 0.893 & 1.355 & 33 & 21 & 9.5 \\
\hline Dec 1982 & 10 & 0.702 & 1.126 & 42 & 29 & 10.8 \\
\hline Oct 1982 & 13 & 0.186 & 0.432 & 26 & 9 & 14.3 \\
\hline \multirow[t]{3}{*}{ Feb 1983} & 5 & 0.852 & 0.876 & 17 & 11 & 6.6 \\
\hline & 10 & 0.730 & 0.690 & 9 & 6 & 6.3 \\
\hline & 13 & 0.993 & 0.945 & 42 & 37 & 6.2 \\
\hline \multirow[t]{3}{*}{ May 1983} & 5 & 0.816 & 1.101 & 30 & 24 & 6.5 \\
\hline & 10 & 0.340 & 0.561 & 102 & 51 & 7.9 \\
\hline & 13 & 0.912 & 1.576 & 27 & 21 & 7.5 \\
\hline
\end{tabular}


Table 2. Limanda ferruginea. Yellowtail flounder consumption rates (wet weight)

\begin{tabular}{|c|c|c|c|}
\hline & Stn 5 & Stn 10 & Stn 13 \\
\hline \multicolumn{4}{|l|}{ Consumption per fish $\left(\mathrm{kg} \mathrm{yr}^{-1}\right)$} \\
\hline Bioenergetic method & 1.60 & 1.37 & 1.53 \\
\hline Stomach-content method & 0.82 & 0.60 & 0.48 \\
\hline $\begin{array}{l}\text { Yellowtail flounder density } \\
\text { (fish } \mathrm{m}^{-2} \text { ) }\end{array}$ & $2.01 \times 10^{-3}$ & $2.01 \times 10^{-3}$ & $4.13 \times 10^{-3}$ \\
\hline 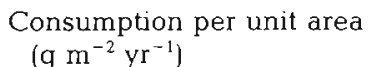 & $1.65-3.23$ & $1.22-2.75$ & $1.98-6.32$ \\
\hline
\end{tabular}

The mean-stomach-content method (Eqn 3) is applicable to the cases with smaller sample sizes. Daily ration, estimated from Eqn (3) and the mean stomach-content weights $(\overline{\mathrm{S}})$ in Table 1 , is plotted in Fig. 3 against time of year. The $95 \%$ confidence intervals include the variance of mean stomach-content weight but not the error in estimating $r$ (gastric evacuation rate). If this error were known and included, the confidence intervals would be even larger. As expected, for August 1982 and May 1983 at Stn 10, the consumption rates obtained by the change-instomach-content method are identical to those obtained by the mean-stomach-content method.

No clear seasonal trend in consumption rate is apparent in Fig. 3. According to Eqn (2), daily ration is the product of mean stomach-content weight and evacuation rate. Because the evacuation rate is a function of temperature, it is higher in summer and fall than in winter and spring. Consumption at Stns 5 and 10 was highest in summer and fall owing to the warm temperatures, while consumption at Stn 13 was lowest in summer and fall because of the low stomach-content weights. Among-station differences in consumption rates were insignificant $(p>0.1)$ as tested by 2 -way ANOVA without replication. Annual consumption, corresponding to the area under each line in Fig. 3, was $0.824,0.605$, and $0.477 \mathrm{~kg}$ wet wt $\mathrm{fish}^{-1} \mathrm{yr}^{-1}$ at Stns 5, 10 and 13, respectively. Because of the large variance of daily ration, these values are not statistically different from one another, but they are about half or less than half the consumption rates estimated by the bioenergetic method (Table 2).

Observed and estimated relative abundance of yellowtail flounder is plotted, for the Georges Bank and Southern New England populations, in Fig. 4 \& 5 . Population size is obtained by dividing the estimated relative-abundance index by the catchability coefficient. The population estimates, for fall 1982, are 64.9 million fish for Georges Bank and 117.0 million fish for Southern New England.

These population estimates apply to an area bounded by the $100 \mathrm{~m}$ isobath because yellowtail flounder are rarely caught below this depth (Lux \&
Livingston 1982). I summed the areas of the appropriate survey strata for each of the 2 flounder populations. The survey strata corresponding to the Georges Bank population cover an area of $32329 \mathrm{~km}^{2}$, and yellowtail flounder density on Georges Bank in fall 1982 was thus 20.1 fish ha ${ }^{-1}$. For the Southern New England population, the corresponding survey strata cover a total area of $28294 \mathrm{~m}^{2}$, giving a 1982 yellowtail flounder density of 41.3 fish $\mathrm{ha}^{-1}$. To calculate consumption rate per unit area, I multiplied these density estimates by the consumption rate per fish, using the estimates based on stomach contents as lower ranges of consumption and the estimates based on bioenergetics as upper ranges (Table 2).

Annual production rates of 6 important prey species are listed in Table 3. Using the appropriate body composition data, I converted the production data for the sand dollar Echinarachnius parma (Battelle \& WHOI 1985) from units of dry weight to wet weight. Sizefrequency data for Chone infundibuliformis at Stn 13

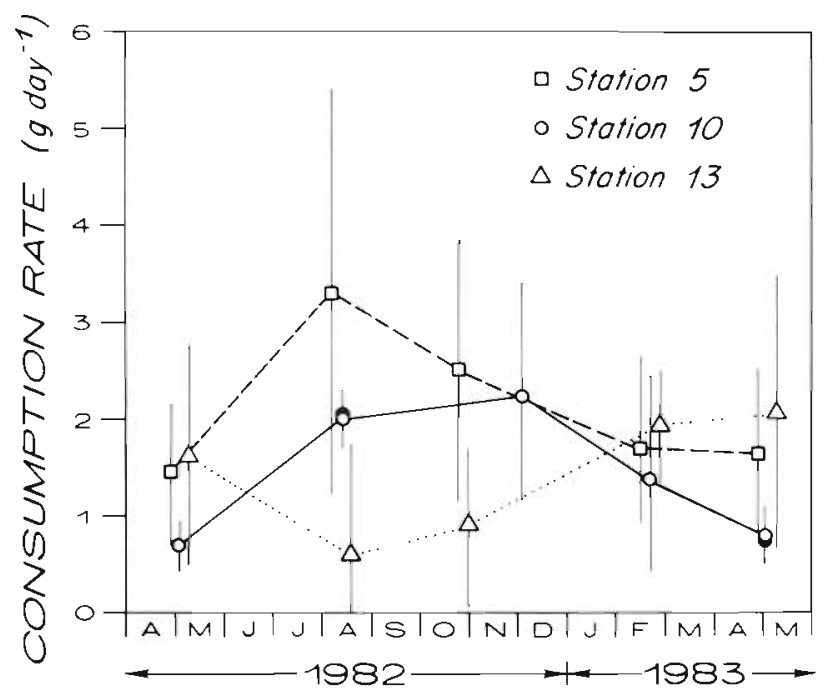

Fig. 3. Limanda ferruginea. Rate of food consumption by yellowtail flounder estimated by the mean-stomach-content method. Units are $\mathrm{g}$ wet $\mathrm{wt} \mathrm{d}^{-1}$. Vertical lines are $95 \%$ confidence intervals. The partially eclipsed solid dots represent consumption estimated by the change-in-stomach-content method. See text for explanation of methods 


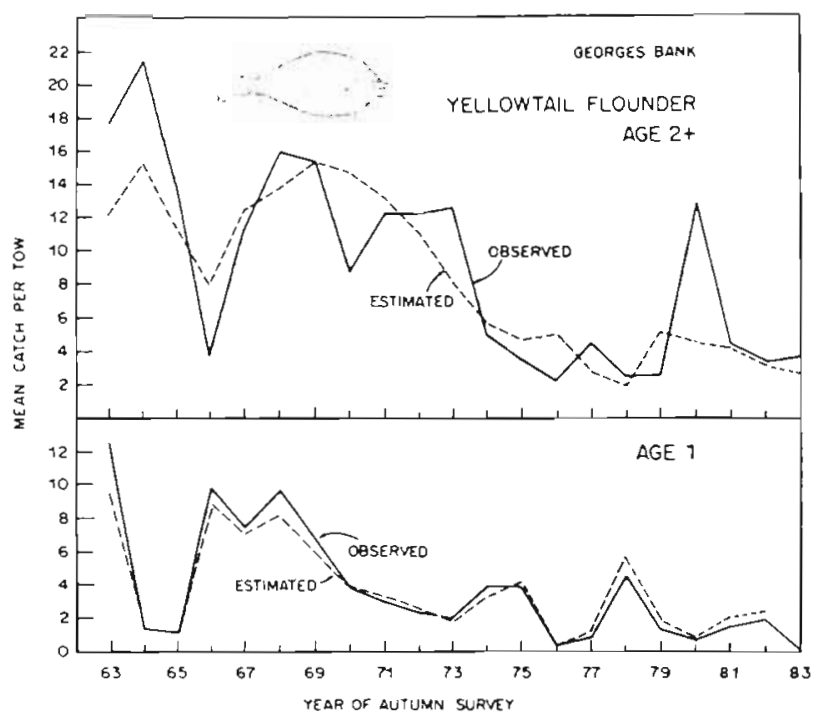

Fig. 4. Limanda ferruginea. Relative abundance of Georges Bank yellowtail flounder in the NEFC groundfish survey. Redrawn from Collie \& Sissenwine (1983)

(Batelle \& WHOI 1985) were pooled and standardized to number per $\mathrm{m}^{2}$ before applying the size-frequency method (Eqn 5) to calculate production (Table 4).

I used the $\mathrm{P} / \mathrm{B}$ value of $2.83 \mathrm{yr}^{-1}$ from Stn 13 to estimate Chone infundibuliformis production at Stn 5 (for which size measurements were not made). The mean biomass at Stn $5,0.47 \mathrm{~g}$ wet $\mathrm{wt} \mathrm{m}^{-2}$, was multiplied by 1.15, to account for weight loss due to preservation of the worms in alcohol, and then multiplied by $\mathrm{P} / \mathrm{B}$ to obtain the production estimate of $1.52 \mathrm{~g}$ wet wt $\mathrm{m}^{-2} \mathrm{yr}^{-1}$. The same approach was used to estimate production of Nephtys incisa at Stn 13. Again, I multiplied the mean biomass, $2.29 \mathrm{~g}$ wet wt $\mathrm{m}^{-2}$, by 1.15 and by the mean of the P/B values determined by Sanders (1956) and Howe \& Leathem (1984).

Consumption as a percentage of prey production was highest for the 2 polychaete species, intermediate for the 3 amphipod species and insignificantly low for the

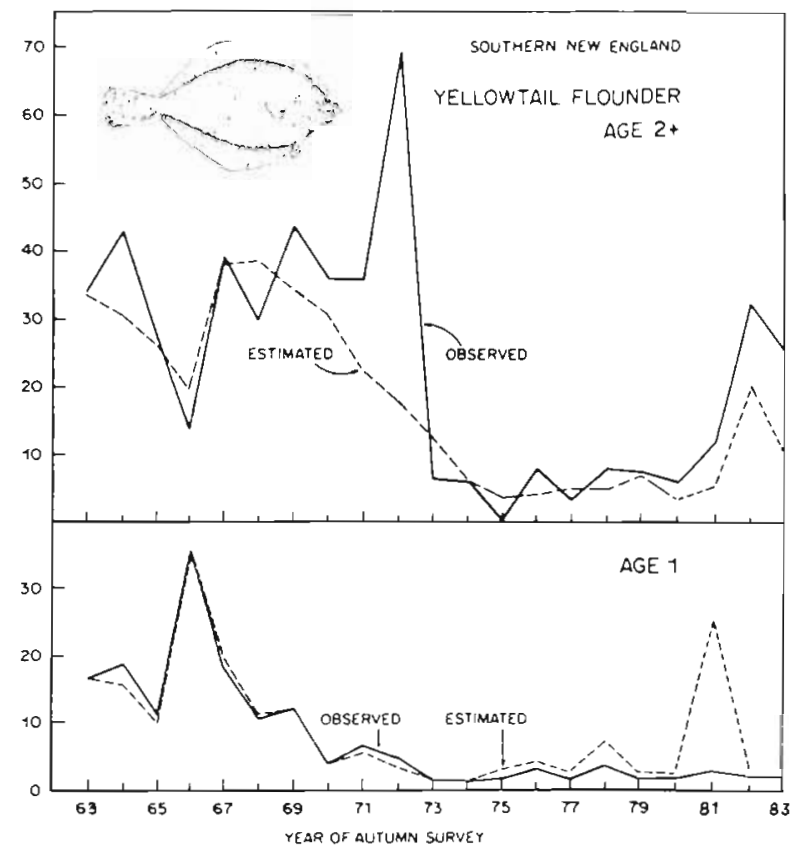

Fig. 5. Limanda ferruginea. Relative abundance of Southern New England yellowtail flounder in the NEFC groundfish survey. Redrawn from Collie \& Sissenwine (1983)

sand dollar. The 6 prey species for which consumption was estimated were all important in the yellowtail flounder diet on a weight basis (Fig. 1). These diet composition data, converted to percentages (Table 3), were used to partition the consumption per unit area for each station (Table 2). Finally, the consumption rate of each species was divided by the corresponding prey production rate to obtain the final column of Table 3 .

\section{DISCUSSION}

The diel pattern in stomach-content weight (Fig. 2) is consistent with that reported in 2 previous studies of yellowtail flounder food habits (Bowman 1980, Lang-

Table 3. Limanda ferruginea. Yellowtail flounder consumption as a percentage of prey production. Production estimates of $U$. inermis, E. fasciatus and A. agassizi are from Collie (1985b); production of E. parma was estimated in Batelle \& WHOI (1985). (WW: wet weight)

\begin{tabular}{|lcccc|}
\hline Prey species & Station & $\begin{array}{c}\text { Production } \\
\text { (g WW } \mathrm{m}^{-2} \mathrm{yr}^{-1} \text { ) } \\
\text { Jul 82-Jul 83 }\end{array}$ & $\begin{array}{c}\text { Percent of } \\
\text { flounder diet } \\
\text { (by weight) }\end{array}$ & $\begin{array}{c}\text { Consumption } \\
\text { Production }\end{array}$ \\
\hline Unciola inermis & 5 & 8.93 & 31.8 & $5.88-11.50$ \\
Ericthonius fasciatus & 5 & 13.08 & 18.8 & $2.37-4.64$ \\
Chone infundibuliformis & 5 & 1.52 & 9.8 & $10.64-20.83$ \\
C. infundibuliformis & 13 & 6.60 & 35.4 & $10.62-33.90$ \\
Nephtys incisa & 13 & 11.58 & 20.1 & $6.61-21.10$ \\
Ampelisca agassizi & 13 & 97.14 & 5.2 & $0.89-2.84$ \\
Echinarachnius parma & 10 & & 2.6 & $0.03-0.07$ \\
\hline
\end{tabular}


Table 4. Chone infundibuliformis production (wet weight) at Stn 13 from Jul 1982 to Jul 1983

\begin{tabular}{|c|c|c|c|c|c|c|}
\hline $\begin{array}{l}\text { Mean number } \\
\overline{\bar{N}}\left(\mathrm{~m}^{-2}\right)\end{array}$ & $\begin{array}{l}\text { Mean length } \\
\mathrm{L}(\mathrm{mm})\end{array}$ & $\begin{array}{l}\text { Mean weight } \\
\text { w (mg) }\end{array}$ & $\begin{array}{l}\text { Geometric mean wt } \\
\qquad\left(w_{j} w_{\jmath+1}\right)^{0.5}\end{array}$ & $\frac{\text { Biomass }}{\mathrm{N} w(\mathrm{mg})}$ & Number removed & $\begin{array}{l}\text { Biomass removed } \\
\bar{N}\left(w_{1} w_{1+1}\right)^{0.5}\end{array}$ \\
\hline 4.88 & 12.5 & 13.0 & - & 63.4 & - & - \\
\hline 11.75 & 17.5 & 31.0 & 20.1 & 364.3 & -6.87 & -138.1 \\
\hline 12.71 & 22.5 & 59.4 & 42.9 & 755.0 & -0.96 & -41.2 \\
\hline 8.58 & 27.5 & 99.9 & 77.0 & 857.1 & 4.13 & 318.0 \\
\hline 1.92 & 32.5 & 154.0 & 124.0 & 295.7 & 6.66 & 825.8 \\
\hline- & 37.5 & 223.1 & 185.4 & - & 1.92 & 355.2 \\
\hline \multicolumn{2}{|c|}{ Total biomass removed: } & $1.32 \mathrm{~g} \mathrm{~m}^{-2}$ & & & & \\
\hline \multicolumn{2}{|c|}{ Times number of size classes: } & 5 & & & & \\
\hline \multicolumn{2}{|c|}{ Production: } & $6.60 \mathrm{~g} \mathrm{~m}^{-2} \mathrm{yr}^{-1}$ & & & & \\
\hline \multicolumn{2}{|c|}{ Biomass: } & $2.34 \mathrm{~g} \mathrm{~m}^{-2}$ & & & & \\
\hline \multicolumn{2}{|c|}{ Production/biomass: } & $2.82 \mathrm{yr}^{-1}$ & & & & \\
\hline
\end{tabular}

ton 1983). In both studies stomach-content weight was highest between 1800 and $2100 \mathrm{~h}$, decreased from 2100 to $0300 \mathrm{~h}$ and was lowest from 0300 to $1200 \mathrm{~h}$. Thus yellowtail flounder are daytime feeders with peak food consumption in the afternoon to early evening. Some flounder probably feed at a slower rate throughout the day and night. In the evening, stomach contents accumulate faster than they are digested, resulting in the stomach-content weight maximum.

The change-in-stomach-content method (Eqn 2) of estimating consumption is equivalent to the meanstomach-content method (Eqn 3) provided that stomach-content weight is roughly the same at the beginning and end of the feeding cycle. In my study, the assumption of a diel feeding pattern was fulfilled and the 2 methods produced similar results in the 2 cases to which both were applied. This justified the use of the mean-stomach-content method in cases with small sample sizes.

Compared to consumption rates of other North Atlantic fishes (Collie 1985b), especially those of winter flounder, the bioenergetic estimate for yellowtail flounder does not seem too high. The C/B value calculated by Grosslein et al. (1980) is a weighted mean over all ages for the years 1963 to 1972 . The age distribution has not changed much since then (Clark et al. 1984) so the C/B value remains appropriate to 1982 consumption. A 3 yr old yellowtail flounder will grow about $175 \mathrm{~g}$ in $1 \mathrm{yr}$. If growth efficiency is $15 \%, 1.2 \mathrm{~kg}$ of food would be required for growth alone. Viewed in this light, the stomach-content consumption estimates seem too low. A partial explanation of the low estimates is that the fish stomachs were fixed in formalin and transferred to alcohol before the contents were weighed, but this bias would only account for a $15 \%$ weight loss (Mills et al. 1982). Another possibility is that the evacuation rate is underestimated by Eqn (4).

A major problem in relating fish consumption to benthic production is the scale of sampling. The estimates of flounder abundance apply to all of Georges Bank, while the prey production rates are based on $0.5 \mathrm{~m}^{2}$ of sea bottom. Although the survey catch per tow is tabulated stratum by stratum, there is no obvious way of weighting the Collie \& Sissenwine (1983) method in order to estimate fish abundance in one particular stratum. The population abundances based on catch statistics cannot be gross overestimates because there must have been at least as many yellowtail flounder as the number caught commercially.

In analyzing a compartmental energy budget of the Georges Bank ecosystem, Sissenwine (1984) found that fish as a group consume 30 to $50 \%$ of the production of their potential prey. He concluded that food probably limits production of some species or life stages, and in particular, food may have been limiting when fish biomass was higher, prior to overfishing. If food is limiting, density-dependent growth, as observed in haddock (Grosslein et al. 1980), is likely.

From the results in Table 3 we can infer that food consumption by yellowtail flounder is not limited by prey production because there is excess prey production not utilized by flounder. However, yellowtail flounder population size was much lower from 1981 to 1983 compared to the earlier period, 1963 to 1965 (Fig. $4 \& 5$ ). The flounder population is especially reduced on Georges Bank; in the Southern New England area, flounder abundance has increased thanks to the strong 1980 year class.

Using my population estimates I calculated consumption by flounder in 1963 as 6.0 to $11.7 \mathrm{~g}$ wet wt $\mathrm{m}^{-2} \mathrm{yr}^{-1}$ at Stn 5 and 3.7 to $11.7 \mathrm{~g}$ wet $\mathrm{wt} \mathrm{m}^{-2} \mathrm{yr}^{-1}$ at Stn 13. My estimates are higher than those of Grosslein et al. (1980) because of revised population estimates and because, in calculating flounder density, I used the area of strata where yellowtail flounder are caught instead of the entire area of Georges Bank. At the 1963 population levels, if consumption rates per fish and prey-production rates equalled 1982 levels, the con- 
sumption rates in Table 3 would be increased by a factor of 3.6 at $\operatorname{Stn} 5$ and by 1.8 at $\operatorname{Stn} 13$. Given these assumptions, yellowtail flounder would consume up to $50 \%$ of the annual production of the prey species in Table 3 ; at these consumption levels, prey production could limit feeding.

If yellowtail flounder feeding were limited by prey production, one would expect Persson's (1981) hypothesis for the Baltic Sea to apply to Georges Bank. This hypothesis states that as flounder abundance decreases, individual growth rates should increase because of decreased competition for food, and the biomass of benthic macrofauna should increase. To test the growth-rate hypothesis, I plotted mean length-at-

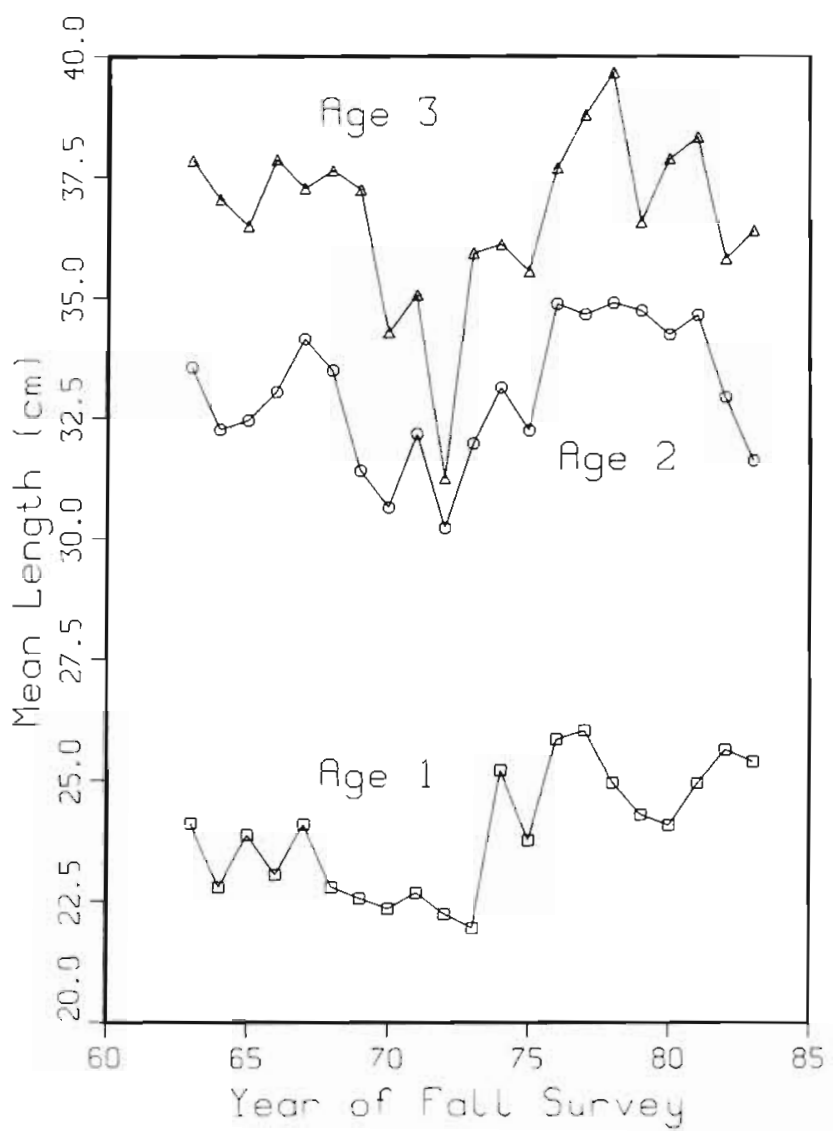

Fig. 6. Limanda ferruginea. Mean length-at-age of Georges Bank yellowtail flounder in the NEFC groundfish survey. These data were provided courtesy of Margaret McBride, NEFC

age of yellowtail flounder caught during the fall groundfish survey from 1963 to 1983 (Fig, 6). Mean lengths are shown for ages 1,2 and 3 only, because the sample sizes of older ages were too small to calculate reliable means. Especially for age 1 fish, mean lengths-at-age were higher from 1974 to 1983 when flounder were less abundant, and lower from 1963 to 1973 when flounder were more abundant. This is con- sistent with the growth-rate hypothesis but there is a good deal of year-to-year variability not explained by density-dependent growth.

Although several Georges Bank surveys have measured benthic biomass (e.g. Wigley 1968, Michael et al. 1983, Battelle \& WHOI 1985), a direct comparison of the results is hampered by the fact that different stations were sampled and different methods were used on each survey. One problem with wet-weight biomass data is that a few large species with hard parts, such as Arctica islandica and Echinarachnius parma, completely dominate the biomass when present. Even if the weights of these large species are excluded, methodological differences preclude a valid comparison among benthic surveys. On more recent surveys, increasingly finer sieves, which retain more animals, have been used. Biomass may thus appear to increase regardless of real changes in the benthos.

The results in Table 3 show that yellowtail flounder consume a small but significant proportion (up to $33 \%$ ) of the production of important prey species. To some extent, flounder may thus regulate the abundance of benthic macrofauna. The remaining portion of prey production, not eaten by flounder, is probably consumed by other demersal fish and invertebrate species. A number of fishes, such as haddock Melanogrammus aeglefinus, eat amphipods; others, such as cod Gadus morhua, feed on amphipods as juveniles, switching to larger prey as adults. Ampelisca spp., Unciola spp. and Ericthonius spp. are among the most numerous prey of these fishes (Bowman \& Michaels 1984).

For the polychaete feeders, including haddock and witch flounder Glyptocephalis cynoglossus, worms of the families Sabellidae, Nephtyidae and Lumbrineridae are important prey. The American plaice Hippoglossoides platessoides specializes in eating the sand dollar Echinarachnius parma. Although the diets of these fishes are well documented, consumption rates and abundances can be calculated only for a few of them. The combined predation by this guild of benthic-feeding fish should be substantially more than that of yellowtail flounder alone. Together, these predators could regulate the abundance of their benthic prey.

Acknowledgements. Dr. J. F. Grassle was instrumental in planning this study. Dr. M. D. Grosslein (NEFC) scheduled the fish-stomach sampling. Ray Bowman and Bill Michaels collected many of the fish stomachs. Frank Aimeida and Margaret McBride kindly provided unpublished fisheries data. Carla Curran produced the data on sand dollar production. Drs. M. P. Sissenwine, E. Ursin, C. R. Smith and 2 reviewers made helpful comments on earlier versions. This study was funded by the Minerals Management Service, U.S. Department of the Interior, Washington, D.C. Woods Hole Oceanographic Institution contribution No. 6207. 


\section{LITERATURE CITED}

Arntz, W. E. (1980). Predation by demersal fish and its impact on the dynamics of macrobenthos. In: Tenore, K. R., Coull, B. C. (ed.) Marine benthic dynamics. Univ, of South Carolina Press, Columbia, p. 121-150

Battelle and Woods Hole Oceanographic Institution (1985). Georges Bank benthic infauna monitoring program, Vol. 2: Final report, Year Three. U. S. Dept of the Interior, Minerals Management Service, Washington, D. C

Bigelow, H. B., Schroeder, W. C. (1953). Fishes of the Gulf of Maine. Fish. Bull. U.S. Fish. WildI. Serv. 53: 1-577

Bowman, R. E. (1980). Diurnal periodicity in the feeding and catchability of some marine fish and squid. Nat. Mar. Fish. Serv., Woods Hole Lab., Ref. Doc. No. 80-17

Bowman, R. E., Michaels, W L. (1984). Food of seventeen species of Northwest Atlantic fish. NOAA Tech. Mem. NMFS-F/NEC-28

Clark, S. H., McBride, M. M., Wells, B. (1984). Yellowtail flounder assessment update-1984. Nat. Mar. Fish. Serv., Woods Hole Lab., Ref. Doc. No. 84-39

Collie, J. S. (1985a). Life history and production of three amphiod species on Georges Bank. Mar Ecol. Prog. Ser. 22: $229-238$

Collie, J. S. (1985b). Feeding habits of the yellowtail flounder and production of its invertebrate prey on Georges Bank. $\mathrm{Ph}$. D. thesis MIT/WHOI, WHOI-85-32

Collie, J. S., Sissenwine, M. P. (1983). Estimating population size from relative abundance data measured with error. Can. J. Fish. Aquat. Sci. 40: 1871-1879

Crisp, D. J. (1984). Energy flow measurements. In: Holm, N. A., McIntyre, A. D. (ed.) Methods for the study of marine benthos, 2nd edn. IBP Handbook No. 16, Blackwell, Oxford, p. 284-372

Durbin, E. G., Durbin, A. G., Langton, R. W., Bowman, R. E. (1983). Stomach contents of silver hake, Merluccius bilinearis, and Atlantic cod, Gadus morhua, and estimation of their daily rations. Fish. Bull. U.S. 81. 437-454

Eggers, D. M. (1979). Comment on some recent methods for estimating food consumption by fish. J. Fish. Res. Bd Can. 36: 1018-1019

Elliot, J. M., Persson, L. (1978). The estimation of daily rates of food consumption for fish. J. Anim. Ecol. 47: 977-991

Evans, S. (1984). Energy budgets and predation impact of dominant epibenthic carnivores on a shallow soft-bottom community on the Swedish west coast. Estuar. coast. Shelf Sci. 18: 651-672

Fange, R., Grove, D. (1979). Digestion. In: Hoar, W S., Randall, D. J., Brett, J. R. (ed.) Fish physiology, Vol. VIII,
Bioenergetics and growth. Academic Press, New York, p. $162-280$

Grosslein, M. D., Langton, R. W., Sissenwine, M. P. (1980). Recent fluctuations in pelagic fish stocks of the Northwest Atlantic, Georges Bank region in relation to species interactions. Rapp. P. -v. Réun. Cons. int. Explor. Mer 177: $374-404$

Howe, S., Leathem, W. (1984). Secondary production of benthic macrofauna at three stations of Delaware Bay and coastal Delaware. NOAA Tech. Mem. NMFS-F/NEC-32

Krueger, C. C., Martin, F. B. (1980). Computation of confidence intervals for the size-frequency (Hynes) method of estimating secondary production. Limnol. Oceanogr. 25: 773-777

Langton, R. W. (1983). Food habits of yellowtail flounder, Limanda ferruginea (Storer), from off the northeastern United States. Fish. Bull. U.S. 81: 15-22

Lux, F. E., Livingston, R. (1982). Yellowtail Limanda ferruginea. In: Grosslein, M. D., Azarovitz, T. R. (ed.) Fish distribution. MESA New York Bight Atlas Monograph 15: $117-119$

Michael, A. D., Long, C. D., Maurer, D., McGrath, R. A. (1983). Georges Bank benthic infauna historical study, final report. U.S. Dept. of the Interior, Minerals Management Service, Washington, D.C.

Mills, E. L., Pittman, K., Monroe, B. (1982). Effect of preservation on the weight of benthic marine invertebrates. Can. J. Fish. Aquat. Sci. 39: 221-224

Persson, L. E. (1981). Were macrobenthic changes induced by thinning out of flatfish stocks in the Baltic proper? Ophelia 20: $137-152$

Pihl, L. (1985). Food selection and consumption of mobile epibenthic fauna in shallow marine areas. Mar. Ecol. Prog. Ser. 22: 169-179

Sanders, H. L. (1956). Oceanography of Long Island Sound 1952-1954. X. The biology of marine bottom communities. Bull. Bingham oceanogr. Coll. 15: 345-414

Sissenwine, M. P. (1984). Why do fish populations vary? In: May, R. M. (ed.) Exploitation of marine communities. Dahlem Konferenzen, Springer-Verlag, Berlin, p. 59-94

Sissenwine, M. P., Cohen, E. B., Grosslein, M. D. (1984). Structure of the Georges Bank ecosystem. Rapp. P.-v. Réun. Cons. int. Explor. Mer 183: 243-254

Wigley, R. L. (1968). Benthic invertebrates of the New England fishing banks. Bull. Am. Litt. Soc. 5: 8-13

Wildish, D. J., Peer, D. (1983). Tidal current speed and production of benthic macrofauna in the lower Bay of Fundy. Can. J. Fish. Aquat. Sci. 40 (Suppl. 1): 309-321 